\title{
Yetişkin Bireylerin Probiyotik Gıdaları Bilme ve Tüketme Durumları Üzerine Bir Araştırma
}

\author{
Dilek Arduzlar Kağan ${ }^{1 *}$, Tuğçe Özlü${ }^{2}$, Hande Yurttaş ${ }^{3}$ \\ ${ }^{1}$ Bahçeşehir Üniversitesi, Sağlık Bilimleri Fakültesi, Beslenme ve Diyetetik Bölümü, İstanbul, Türkiye (ORCID: 0000-0001-8688-9039) \\ ${ }^{2}$ Araştırma Görevlisi, Bahçeşehir Üniversitesi, Sağlı Bilimleri Fakültesi, Beslenme ve Diyetetik Bölümü, İstanbul, Türkiye (ORCID: 0000-0002-0139-676X) \\ ${ }^{3}$ Bahçeşehir Üniversitesi, Sağlık Bilimleri Fakültesi, Beslenme ve Diyetetik Bölümü, İstanbul, Türkiye (ORCID: 0000-0001-9836-2816)
}

(İlk Geliş Tarihi 29 Temmuz 2019 ve Kabul Tarihi 27 Eylül 2019)

(DOI: $10.31590 /$ ejosat.598208)

ATIF/REFERENCE: Arduzlar Kağan, D., Özlü, T. \& Yurttaş, H. (2019). Yetişkin Bireylerin Probiyotik Gıdaları Bilme Ve Tüketme Durumları Üzerine Bir Araştırma. Avrupa Bilim ve Teknoloji Dergisi, (17), 556-563.

\section{$\ddot{O} \mathbf{z}$}

Probiyotikler, yeterli miktarda alındığında konakçı sağlığı üzerine olumlu etkileri olan canlı mikroorganizmalar olarak tanımlanmaktadır. Probiyotiklerle ilgili yapılan kapsamlı çalışmalar, probiyotiklerin hastalıklar üzerindeki tedavi edici etkisi üzerinde yoğunlaşırken, bireylerin probiyotik gıda tüketim durumlarını gösteren fazla sayıda çalışmaya literatürde rastlanmamıştır. Bu araştırma yetişkin bireylerin probiyotik gıda tüketim durumları ile bu gıdalar hakkında bilgi düzeylerinin değerlendirilmesi amacıyla İstanbul İlinde yaşayan 18-45 yaş arası 66 kadın ve 44 erkek olmak üzere toplam 110 yetişkin birey üzerinde gerçekleştirilmiştir. Katılımcılara araştırmacılar tarafından yüz yüze anket uygulanarak probiyotik gıda tüketim durumları ve gıdalar hakkındaki bilgi düzeyleri belirlenmiştir. Katılımcıların \%64,5'i probiyotik gıda terimini bildiğini, \%73,6'sı probiyotik gıdaları tükettiklerini beyan etmişlerdir. Probiyotik gıda tüketmediğini söyleyen katılımcıların \%45,2'si probiyotik gıda terimini bilmedikleri için, \%23,8'i ise probiyotik gıdaları pahalı buldukları için tercih etmedikleri tespit edilmiştir. Katılımcıların cinsiyet, yaş ve sağlık durumu incelendiğinde kadınların erkeklere göre probiyotik gıda kavramını anlamlı şekilde daha fazla bildiği bulunmuştur. Yaş grupları ve sağlık problemi varlığına göre ise probiyotik gıdaların bilinilirliği ve tüketim oranları arasında istatistiksel olarak anlamlı bir farklılık bulunmamıştır. Katılımcıların \%30,4'ü probiyotik gıdaların düzenli tüketiminin bağırsak sisteminin düzenlenmesi ve kolon kanserine karşı koruyucu olduğu konusunda ve \%52,7'si probiyotik gıdaların düzenli tüketiminin kolesterolün azaltılması ve kalp-damar hastalıklarına karşı koruyucu olduğu konusunda kararsız kalmışlardır. Bireylerin \%64,3’ü ise probiyotik gıdaların düzenli tüketiminin bağışıklık sisteminin aktivasyonunda etkili olduğunu belirtmişlerdir. Sağlığı koruyucu ve geliştirici etkileri olan probiyotikler hakkında toplumda var olan bilgi eksikliği bu besinlerin tüketimini de engellemektedir. Sonuç olarak, probiyotik gıdaların sağlık üzerine olan katkıları daha fazla bireye ulaşmalı ve bu gıdaların tüketim sıklıklarının arttırılması için gerekli müdahaleler planlanmalıdır.

Anahtar Kelimeler: Probiyotik, Gıda, Beslenme, Mikrobiyota, Sağlık

\section{A Research on the Knowledge and Consumption of Probiotic Foods in Adults}

\begin{abstract}
Probiotics are defined as living microorganisms that have positive effects on host health when taken in sufficient amounts. While extensive studies on probiotics have focused on the therapeutic effect of probiotics on diseases, a large number of studies showing the probiotic food consumption status of individuals have not been found in the literature.

The aim of this study is to evaluate the probiotic food consumption of adults and their knowledge about these foods. The study was conducted on 110 adult individuals (66 females and 44 males) aged between 18-45 years living in Istanbul. A face-to-face
\end{abstract}

\footnotetext{
* Sorumlu Yazar: Dr.Öğr.Üyesi, Bahçeşehir Üniversitesi, Sağlık Bilimleri Fakültesi, Beslenme ve Diyetetik Bölümü, İstanbul, Türkiye, ORCID: 0000-0001-8688-9039, dilek.arduzlarkagan@ @es.bau.edu.tr
} 
questionnaire was applied to the participants to determine the level of knowledge about probiotic food consumption and foods. $64.5 \%$ of the participants knew the term probiotic food and $73.6 \%$ of the participants stated that they consumed probiotic foods. It was found that $45.2 \%$ of the participants who stated that they did not consume probiotic food did not know the term probiotic food and $23.8 \%$ did not prefer probiotic food because they found it expensive. When the gender, age and health status of the participants were examined, it was found that women know the concept of probiotic food significantly more than men. There was no statistically significant difference between the knowledge and consumption rates of probiotic foods according to age groups and the presence of health problems. $30.4 \%$ of the participants were uncertain that regular consumption of probiotic foods was protective against the regulation of the intestinal system and colon cancer and $52.7 \%$ were uncertain that regular consumption of probiotic foods was protective against cholesterol reduction and cardiovascular diseases. $64.3 \%$ of individuals stated that regular consumption of probiotic foods is effective in the activation of the immune system. As a result, the effects on health of probiotic foods should be explain more individuals and interventions should be planned to increase the frequency of consumption of these foods. The lack of knowledge about the probiotics that have health-protective and improving effects prevents the consumption of these foods. In conclusion, the contribution of probiotic foods to health should reach more individuals and interventions should be planned to increase the frequency of consumption of these foods.

(Minimum 250 - Maximum of 400 words and content should be written in a way to include material, method, findings and results.)

Keywords: Probiotic, Food, Nutrition, Microbiota, Health

\section{Giriş}

Bağırsak mikrobiyotası; insanlarda beslenme başta olmak üzere, fizyolojik, metabolik, immünolojik birçok olayda etkin rol oynamaktadır. Bağırsak mikrobiyotasının sağlık üzerine etkilerini inceleyen çalışmalara olan ilgi her geçen gün artmaktadır. Faydalı bakterilerin azalıp zararlı bakterilerin artması olarak adlandırılan mikrobiyal disbiyozisin; obezite, diyabet, metabolik sendrom ve gastrointestinal hastalıklar ile ilişkili olduğu hem hayvan modellerinde hem de insan çalışmalarında ortaya çıkarılmıştır (McCabe ve ark., 2015; Altuntaş ve Batman, 2017).

Günlük beslenmenin bir parçası olan fonksiyonel gıdalar sağlığı olumlu yönde etkileyen, kardiyovasküler hastalıklar, enfeksiyonlar, kanser, diyare, konstipasyon ve osteoporoz gibi birçok hastalığı önleyebilen doğal maddelerdir (Milner, 1999). Fonksiyonel gıdaların bağırsak mikrobiyotasının gelişimini, metabolik aktivitesini ve dolayısıyla bileşimi ve fonksiyonlarını etkileyerek sağlık üzerine olumlu etkiler gösterdiği belirtilmiştir (Laparra ve Sanz, 2010). En bilinen fonksiyonel gıdaların başında probiyotik gıdalar gelmektedir (Grajek ve ark., 2005). Probiyotikler, yeterli miktarda alındığında konakçı sağlığı üzerine olumlu etkileri olan canlı mikroorganizmalar olarak tanımlanmaktadır (Johnston ve ark., 2006). Fizyolojik işlevleri geliştirerek sağlığı olumlu yönde etkileyen probiyotikler, patojen mikroorganizmaların çoğalmasını baskılamaktadır (Coşkun, 2006). Probiyotiklerle ilgili son yıllarda yapılan çalışmalarda sağlık üzerindeki etkisinin yalnızca mikroorganizma hücrelerinden dolayı değil, metabolitlerinden dolayı da kaynaklandığını söylenmektedir (Aydın ve ark., 2010). Probiyotiklerin antibiyotik kaynaklı ishaller, atopik hastalıklar ile enflamatuvar barsak hastalıkları tedavisinde etkili olduğu, bağışıklık sistemini destekleyerek enfeksiyonlara karşı koruyucu etkileri olduğu bilinmektedir (Derin ve Keskin, 2013). Obezite, non alkolik yağlı karaciğer hastalığı, tip 2 diyabet, çeşitli kanser türleri, kardiyovasküler hastalıklar gibi kronik hastalıklara karşı koruyucu etkileri de olan probiyotiklerle ilgili çalışmalar (Ejtahed ve ark.,2011; Ethajed ve ark., 2012;Saez ve ark., 2016; Nazarii ve ark., 2016; Ambalam ve ark., 2016; Yu ve Li, 2016; Liu ve ark., 2017) çoğunlukla probiyotiklerin hastalıklar üzerinde nasıl bir mekanizma ile koruyucu ve tedavi edici etki gösterdiği üzerinde yoğunlaşırken, probiyotik gıda tüketim durumlarını gösteren çok fazla çalışmaya literatürde rastlanmamıştır.

$\mathrm{Bu}$ çalışmada İstanbul ilinde yaşayan yetişkin bireylerin probiyotik gıda tüketim durumları ile bu gıdalar hakkında bilgi düzeylerini belirlemek ve cinsiyet, yaş ve sağlık durumunun probiyotik gıda tüketimini ve probiyotik gıdalar hakkında var olan bilgi düzeyini nasıl etkilediğini saptamak amaçlanmıştır.

\section{Materyal ve Metot}

Araştırma yetişkin bireylerin probiyotik gıdaları tüketim durumları ve bilgi düzeylerini belirlemek amacıyla Şubat- Mart 2016 ayları arasında İstanbul ilinde yaşayan 18-45 yaş arası 66 kadın ve 44 erkek olmak üzere toplam 110 yetişkin birey üzerinde gerçekleştirilmiştir. Katılımcılara araştırmacılar tarafından benzer çalışmalar örnek alınarak hazırlanan, kişisel bilgiler, genel sağlık bilgileri, probiyotik gıdalarla ilgili bilgi düzeyleri ve probiyotik gıda tüketim sıklığının sorgulandığı 4 bölümden oluşan bir anket uygulanmıştır. Anketler yüz yüze görüşme yöntemiyle gerçekleştirilmiştir.

\subsection{Verilerin Değerlendirilmesi}

Çalışmadan elde edilen bulgular değerlendirilirken, istatistiksel analizler için SPSS (Statistical Package for Social Sciences) for Windows 20,0 programı kullanılmıştır. Çalışma verileri değerlendirilirken tanımlayıcı istatistiksel metodların yanı sıra niteliksel verilerin karşılaştırılmasında Ki-Kare testi ve Frequency testi uygulanmıştır. Anlamlılık p <0.05 düzeyinde değerlendirilmiştir. 


\section{Araştırma Sonuçları ve Tartışma}

Kelime anlamı "yaşam için uygun” olan probiyotik kavramı, yeterli miktarda alındığında sağlığa olumlu etkileri olan canlı mikroorganizmalar olarak tanımlanmaktadır. Probiyotik gıdalar ise bağırsak mikroflora dengesini geliştirerek sağlığı olumlu etkileyen bu canlı mikroorganizmaları yeterli miktarda içeren gıdalardır (Gandhi ve Shah, 2017). Gıda, Tarım ve Hayvancılık Bakanlığı tarafından 2011 yılında yayınlanan Türk Gida Kodeksi Etiketleme Yönetmeliği'ne göre bir gıdanın probiyotik olarak tanımlanabilmesi için en az 1x106 koloni oluşturan birim (kob)/gram probiyotik mikroorganizma içermesi gerekmektedir (Gıda, Tarım ve Hayvancılık Bakanlığı, 2011). Bu gıdaların tüketimi uzun yıllara dayansa da bilim topluluğunda probiyotik gıdaların sağlık etkilerinin ortaya çıkarılması 1900'lere dayanmaktadır (Gandhi ve Shah, 2017). Günümüzde probiyotik gıdalarla ilgili yapılan çalışmalar bu gıdaların sağlığı hangi yollarla etkilediği üzerine planlanırken probiyotik gıda tüketim durumunu ortaya koyan çalışmalar hala eksikliğini sürdürmektedir.

Bu çalışma İstanbul ilinde yaşayan 18 - 45 yaş arasında 66'sı kadın, 44'ü erkek 110 kişinin probiyotik gıdalar hakkında bilgi düzeylerini ve probiyotik gıda tüketim durumlarını saptamak ve cinsiyet, yaş, sağlık durumu gibi faktörlerin bilgi düzeylerini ve tüketim durumlarını ne derece etkilediğini ortaya koymak amacıyla gerçekleştirilmiştir. Katılımcıların çoğu üniversite mezunudur (\%62,7). Bireylerin 18-24, 25-34 ve 35-45 yaş arasında eşit dağıldığı görülmektedir. Katılımcıların çoğunun herhangi bir sağlık sorunu bulunmamakla birlikte $(\% 54,5)$, bireylerin $\% 39$ 'u sigara, $\% 41,8$ 'i ise alkol kullanmaktadır (Tablo 1).

Tablo 1. Katılımcılar İle Illgili Tanımlayıc bilgiler $(N=110)$

\begin{tabular}{|c|c|c|}
\hline & Sayı (n) & Yüzde (\%) \\
\hline \multicolumn{3}{|l|}{ Cinsiyet } \\
\hline Kadın & 66 & 60,0 \\
\hline Erkek & 44 & 40,0 \\
\hline \multicolumn{3}{|l|}{ Yaş } \\
\hline $18-24$ & 39 & 35,5 \\
\hline $25-34$ & 40 & 36,4 \\
\hline $35-45$ & 31 & 28,1 \\
\hline \multicolumn{3}{|l|}{ Öğrenim Durumu } \\
\hline İlkokul & 7 & 6,4 \\
\hline Lise & 29 & 26,4 \\
\hline Üniversite & 69 & 62,7 \\
\hline Master/Doktora & 5 & 4,5 \\
\hline \multicolumn{3}{|l|}{ Meslek } \\
\hline Çalışmıyor/Ev Hanımı & 3 & 2,7 \\
\hline Memur & 38 & 34,6 \\
\hline Öğrenci & 25 & 22,7 \\
\hline Diğer & 44 & 40,0 \\
\hline \multicolumn{3}{|l|}{ Sigara Kullanımı } \\
\hline Evet & 43 & 39,0 \\
\hline Hayır & 67 & 61,0 \\
\hline \multicolumn{3}{|l|}{ Alkol Kullanımı } \\
\hline Evet & 46 & 41,8 \\
\hline Hayır & 64 & 58,2 \\
\hline \multicolumn{3}{|l|}{ Var olan hastalıklar } \\
\hline Sağlık problemi olmayan & 60 & 54,5 \\
\hline Diyabet & 9 & 8,2 \\
\hline Böbrek hastalığ1 & 2 & 1,8 \\
\hline Diş problemleri & 9 & 8,2 \\
\hline Anemi & 9 & 8,2 \\
\hline Göz rahatsızlığı & 18 & 16,4 \\
\hline Kalp damar hastalığ1 & 3 & 2,7 \\
\hline
\end{tabular}

Yetişkinlerin probiyotik gıda kavramına ilişkin parametreleri incelendiğinde katılımcıların yarısından fazlası daha önceden probiyotik terimini duyduğunu $(\% 64,5)$ ve probiyotik gıdaları tükettiğini $(\% 73,6)$ belirtmiştir. Probiyotik gida tüketmediğini söyleyen katılımcıların \%45,2'si probiyotik gıda terimini bilmediği için, \%23,8'i ise probiyotik gıdaları pahalı buldukları için tercih etmedikleri tespit edilmiştir. Katılımcıların çoğu $(\% 32,4)$ probiyotik gıda kavramını reklam yolu ile duyduklarını belirtirken \%47,3’ü görsel ve 
yazılı basının probiyotik tüketimini olumlu etkilediğini, $\% 51,8$ 'i ise etkilemediğini bildirmiştir. Katılımcıların \% 13,4'ünün probiyotik gıdaları tek başına, \% 28,9'unun yemekler ile birlikte, \% 57,8'inin ise her iki şekilde de tükettiği belirlenmişstir (Tablo 2).

Tablo 2. Probiyotik Gıda Kavramına İlişkin Parametrelerin Dağılımı

\begin{tabular}{lll}
\hline Parametreler & Sayı (n) & Yüzde (\%) \\
\hline Probiyotik gıda kavramının bilinilirliği & & \\
\hline Evet & 71 & 64,5 \\
Hayır & 39 & 35,5 \\
\hline Probiyotik gıda tüketim durumu & & \\
\hline Evet & 81 & 73,6 \\
Hayır & 29 & 26,4 \\
\hline Probiyotik gıdaları tüketim nedenleri (n=81) & & \\
\hline Reklam (Gazete-Dergi) & 10 & 12,3 \\
Sağlik sorunları & 23 & 28,4 \\
Tavsiye & 34 & 42,0 \\
Diğer & 14 & 17,3 \\
\hline Probiyotik gıda kavramının hangi kaynaktan duyulduğu (n=74) & & \\
\hline Uzman (Diyetisyen/Doktor) & 16 & 21,6 \\
Aile-arkadaş-tanıdık & 20 & 27,0 \\
Reklam(Gazete/Dergi) & 24 & 32,4 \\
Konferans-Bilimsel toplantı & 7 & 9,5 \\
Eczane-Satış noktası & 7 & 9,5 \\
\hline
\end{tabular}

Görsel ve yazılı basının probiyotik tüketimini etkilemesi

\begin{tabular}{lcc}
\hline Olumlu & 52 & 47,3 \\
Olumsuz & 1 & 0,9 \\
Etkilemiyor & 57 & 51,8 \\
\hline Probiyotik gıda tüketim şekli & & \\
\hline Ara öğünlerde & 13 & 11,8 \\
Ana öğünlerde & 28 & 25,5 \\
Her iki şekilde & 56 & 50,9 \\
Hiç tüketmiyorum & 13 & 11,8 \\
\hline
\end{tabular}

Çalışmamıza benzer olarak, Koçak ve Kalkan'ın üniversite öğrencilerinin probiyotik gıdalar hakkındaki bilgi düzeyini ölçmek amacıyla 141 öğrenci üzerinde yürüttükleri çalışmada (2014), katılımcıların \%50,4'ünün probiyotik gıda hakkında bilgi sahibi olduğu belirlenmiştir (Koçak ve Kalkan, 2014). 495 öğrencinin probiyotik gıda tüketim durumlarının incelendiği bir başka çalışmada öğrencilerin \%61,6'sının probiyotik gıdaları tüketmediği, tüketmeme nedenlerinin ise bilmemek ve ihtiyaç duymamak olduğu saptamıştır (Derin ve Keskin, 2013). Anukam ve arkadaşlarının (2005) hekimlerin probiyotiklerle ilgili bilgi düzeylerini belirlemek amacıyla yaptıkları çalışmada katılımcıların \%95,2'sinin probiyotik terimini bilmediği ve tüm katılımcıların konuyla ilgili daha fazla 
bilgi almak istedikleri belirlenmiştir (Anukam, 2006). Stanczak ve Heuburger'in (2009) Amerikalı 335 yetişkin üzerinde yürüttükleri çalışmada katılımcıların \%38,5'i probiyotik terimini daha önce duyduklarını, \% 27,2'si ise probiyotik kavramının ne olduğunu bildiklerini belirtmişlerdir (Stanczak ve Heuberger, 2009).

Çalışmamıza katılan ve probiyotik gıda tüketen yetişkin bireylerin büyük çoğunluğu $(\% 50,9)$ öğünlerle birlikte probiyotik gıda tüketmektedir. Derin ve Keskin'in 495 öğrenci üzerinde yapmış olduğu çalışmada \%62,6's1 probiyotik ürünleri tek başına, \%31,1'i pilav ve makarnayla, \%6,3'ü bisküvi, çikolata gibi gıdalarla tükettikleri belirtilmiştir (Derin ve Keskin, 2013). Sınırlı sayıda çalışmada, probiyotiklerin kısa süreli tüketiminin ad libitum öğünde enerji alımının azalmasına neden olduğu gösterilmiştir (Nabizadehasl, 2018). Bjerg ve arkadaşlarının (2014) 21 katılımcı üzerinde yürüttükleri çift kör randomize çapraz klinik çalışmada, sabit enerji içeren kahvaltı öğünü ile birlikte her katılımcıya plasebo, düşük doz (109 kob/g) veya yüksek doz (1010 kob/g) L. casei W8 içeren kapsül verildikten 240 dakika sonra yüksek doz probiyotik tüketenlerin, plasebo ve düşük doza kıyasla ad libitum öğünün enerji alımında sırasıyla \% 8,5 ve \%15'lik bir azalma kaydedildiği belirlenmiştir (Bjerg ve ark., 2014).

Probiyotik mikroorganizmalar geleneksel fermente bitkisel ürünler, fermente süt ürünleri ve işlem görmüş bazı et ürünlerinde (yoğurt, kefir, ayran, turşu, tarhana, şalgam, şarap, bira, soya, zeytin, sucuk, pastırma, tütsülenmiş et bulunmaktadır (Bell ve ark, 2017). Çalışmamızda probiyotik gıda tüketen katılımcıların büyük çoğunluğu yoğurt $(\% 86,3)$ ve peynir $(\% 66,3)$ tüketirken, soya ve ürünleri $(\% 0,9) \mathrm{kımız}(\% 1,8)$, hardaliye $(\% 1,8)$ gibi spesifik probiyotik gıdaların tüketiminin ise çok az olduğu belirlenmiştir. Probiyotik gıdaların en çok bilinenleri sırasıyla yoğurt $(\% 90,0)$ ve peynir $(\% 66,3)$ iken en az bilinenleri sırasıyla hardaliye $(\% 11,8)$ ve kımızdır $(\% 18,1)$ (Tablo 3). Katılımcıların probiyotik gıda tüketim sıklıkları incelendiğinde $\% 37,2$ oranında günde 1 kez yoğurt tüketildiği, \%39,0 oranında günde $1 \mathrm{kez}$ peynir tüketildiği, \%15,4 oranında günde $1 \mathrm{kez}$ sofralık zeytin tüketildiği tespit edilmiştir. 240 öğrenci ile yapılan bir çalışmada öğrencilerin \%24,4'ü probiyotik gıdaları günde $1 \mathrm{kez}, \% 19,8$ 'i günde 2-3 kez, \%23,3'ü haftada 1 kez, \%11,6's1 ayda 1-3 kez, \%11,6'sı ise nadiren tüketenlerin \%20,9 olduğu bulunmuştur (Yabanc1 ve Şimşek, 2007).

Tablo 3. Katıllmcıların Probiyotik Gıdaları Bilme ve Tüketme Durumları

\begin{tabular}{l|ll|ll}
\hline & \multicolumn{2}{|l|}{ Bilen katılımclar } & \multicolumn{2}{l}{ Tüketen katılımcılar } \\
\hline Probiyotik Gıdalar & $\mathrm{n}$ & $\%$ & $\mathrm{n}$ & $\%$ \\
\hline Yoğurt & 99 & 90,0 & 95 & 86,3 \\
Peynir & 73 & 66,3 & 73 & 66,3 \\
Tereyağı & 47 & 42,7 & 16 & 14,5 \\
Kefir & 63 & 57,2 & 16 & 14,5 \\
Boza & 35 & 31,8 & 5 & 4,5 \\
Kımız & 20 & 18,1 & 2 & 1,8 \\
Tarhana & 31 & 28,1 & 8 & 7,2 \\
Şalgam suyu & 35 & 31,8 & 6 & 5,4 \\
Soya ürünleri & 25 & 22,7 & 1 & 0,9 \\
Sofralık zeytin & 40 & 36,3 & 21 & 19,0 \\
Turşu & 46 & 41,8 & 29 & 26,3 \\
Hardaliye & 13 & 11,8 & 2 & 1,8 \\
\hline
\end{tabular}

Cinsiyet, yaş ve sağlık durumu ile probiyotik gıdaların bilinmesi ve tüketilme durumu incelendiğinde kadınların erkeklere göre probiyotik gıda kavramını anlamlı şekilde daha fazla bildiği bulunmuştur $(\mathrm{p}<0,05)$. Bununla birlikte cinsiyet ile probiyotik gıdaların tüketim oranları arasında istatistiksel olarak anlamlı bir farklılık bulunmamaktadır ( $>>0,05)$. Yaş grupları ve sağlık problemi varlığına göre ise probiyotik gıdaların bilinilirliği ve tüketim oranları arasında istatistiksel olarak anlamlı bir farklılık bulunmamaktadır ( $>0,05)$ (Tablo 4). Çalışmamızın sonucuna benzer olarak Al-Nabulsi ve arkadaşlarının (2014) üniversite öğrencilerinin probiyotik gıdalara yönelik algı ve tutumlarını değerlendirdikleri çalışmada kız öğrencilerinin probiyotik gıdalar hakkında bilgi düzeylerinin erkek öğrencilere göre daha yüksek olduğu belirlenmiştir. Aynı çalışmada yaş grubu ve eğitim düzeyiyle öğrencilerin probiyotik gıdalar hakkında bilgi düzeyleri arasında istatistiksel olarak anlamlı farklılıklar bulunmamıştır (Al-Nabulsi ve ark., 2014). 
European Journal of Science and Technology

\begin{tabular}{|c|c|c|c|c|c|c|}
\hline & \multicolumn{3}{|c|}{ Probiyotik gıda bilinilirliği } & \multicolumn{3}{|c|}{ Probiyotik gıda tüketimi } \\
\hline & Evet & Hayır & $\mathbf{p}$ & Evet & Hayır & $\mathbf{P}$ \\
\hline \multicolumn{7}{|l|}{ Cinsiyet } \\
\hline Kadın & $50(\% 75,8)$ & $16(\% 47,7)$ & & $52(\% 78,8)$ & $29(\% 65,9)$ & \multirow{3}{*}{$\begin{array}{l}\chi 2: 2,256 \\
\text { p: } 0,133\end{array}$} \\
\hline & & & $\chi 2: 9,064$ & & & \\
\hline Erkek & $16(\% 24,2)$ & $23(\% 52,3)$ & p: 0,003 & $14(\% 21,2)$ & $15(\% 51,7)$ & \\
\hline \multicolumn{7}{|l|}{ Yaş grupları } \\
\hline $18-24$ & $28(\% 72,5)$ & $13(\% 31,7)$ & & $31(\% 75,6)$ & $10(\% 24,4)$ & \multirow{4}{*}{$\begin{array}{l}\chi 2: 0,446 \\
\text { p: } 0,800\end{array}$} \\
\hline $25-34$ & $29(\% 72,5)$ & $11(\% 27,5)$ & $\chi 2: 4,712$ & $30(\% 75,0)$ & $10(\% 25,0)$ & \\
\hline & & & p: 0,095 & & & \\
\hline $35-45$ & $14(\% 48,3)$ & $15(\% 51,7)$ & & $20(\% 69,0)$ & $9(\% 31,0)$ & \\
\hline \multicolumn{7}{|l|}{ Sağlık durumu } \\
\hline Şeker hastalığı & $5(\% 55,6)$ & $4(\% 44,4)$ & & $6(\% 66,7)$ & $3(\% 33,3)$ & \multirow{7}{*}{$\begin{array}{l}\chi 2: 6,144 \\
\text { p: } 0,407\end{array}$} \\
\hline Böbrek hastalığı & $1(\% 50,0)$ & $1(\% 50,0)$ & & $0(\% 0,00)$ & $2(\% 100,0)$ & \\
\hline Diş problemleri & $5(\% 55,6)$ & $4(\% 44,4)$ & & $6(\% 66,7)$ & $3(\% 33,3)$ & \\
\hline Kansızlık & $9(\% 100,0)$ & $0(\% 0,00)$ & $\begin{array}{l}\chi 2: 8,065 \\
\text { p: } 0,233\end{array}$ & $5(\% 55,6)$ & $4(\% 44,4)$ & \\
\hline Göz hastalığı & $14(\% 77,8)$ & $4(\% 22,2)$ & & $13(\% 72,2)$ & $5(\% 27,8)$ & \\
\hline Kalp-damar hastalığ & $3(\% 100,0)$ & $0(\% 0,00)$ & & $3(\% 100,0)$ & $0(\% 0,00)$ & \\
\hline Yok & $44(\% 73,3)$ & $16(\% 26,7)$ & & $38(\% 63,3)$ & $22(\% 36,7)$ & \\
\hline
\end{tabular}

Katılımcıların probiyotik gıdaların sağlık etkileri ile ilgili öngörüleri incelendiğinde ise bireylerin \%30,4’ü probiyotik gıdaların düzenli tüketiminin bağırsak sisteminin düzenlenmesi ve kolon kanserine karşı koruyucu olduğu konusunda kararsız kalmıştır (Tablo 5). Bilimsel kanıtlar, diyet, yaşam tarzı ve bağırsak mikrobiyotası bileşimindeki değişiklikler ile kolon kanseri arasında güçlü bir ilişki olduğunu göstermektedir. Bağırsak mikrobiyotasının kolon kanseri gelişimini nasıl etkilediği netlik kazanmasa da mikrobiyotadaki dengesizlikler sebebiyle görülen enflamasyonun kolon kanseri görülme riskini arttırdığı bildirilmektedir (Kumar ve ark., 2015).

Katılımcıların \%64,3’ü probiyotik gıdaların düzenli tüketiminin bağışıklık sisteminin aktivasyonunda etkili olduğunu belirtmişlerdir (Tablo 5). Probiyotikler, doğal immünite, humoral immünite ve sitokinleri etkileyerek patojenlere karşı immün sistem fonksiyonunu geliştirir (Khani ve ark., 2018). Daha spesifik olarak, laktik asit bakterilerinin en yaygın suşları olan Lactobacilli ve Bifidobacteria türlerinin Th1:Th2 sitokin dengesini düzenlemeye yardımcı olduğu bilinmektedir. Ek olarak, birçok çalışma probiyotiklerin fiziksel bariyer fonksiyonu, mukozal bağışıklık sistemi, metabolizma ve sistemik bağışıklık üzerinde faydalı etkilere sahip olduğunu göstermiştir. Ayrıca, probiyotikler atopik hastalıklar, inflamatuar barsak hastalıkları, irritabl bağırsak sendromu ve patojen enfeksiyonları gibi çeşitli hastalıkların tedavisinde kullanılmaktadır (Jeong ve ark., 2016).

Katılımcıların \%52,7'si probiyotik gıdaların düzenli tüketiminin kolesterolün azaltılması ve kalp-damar hastalıklarına karşı koruyucu olduğu konusunda kararsız kalmışlardır (Tablo 5). Literatürdeki son bulgular bağırsakların mikrobiyal dengesizliğinin kardiyovasküler hastalıkların patogenezinde rol oynayabileceğini göstermektedir. Bu nedenle, çeşitli çalışmalar, kardiyovasküler hastalıkların önlenmesi ve/veya tedavisine yönelik bir yaklaşım olarak, bağırsak mikrobiyotasının probiyotiklerle düzenlenmesi yönüne değinmiştir (Thushara ve ark., 2016). Hendijani ve Akrabi’nin (2017) tip 2 diyabetli erişkinlerde kardiyovasküler risk faktörlerinin yönetimi ile probiyotik desteği arasındaki ilişkiyi açıklamayı amaçladıkları meta analiz çalışmasında, toplam 641 kişinin dâhil olduğu 11 randomize kontrollü çalışma incelenmiştir. Çalışmanın sonuçlarına göre tip 2 diyabetli hastalarda probiyotik tüketiminin plasebo grubuna kıyasla sistolik ve diyastolik kan basıncını, LDL kolesterol, total kolesterol ve trigliserit seviyelerini anlamlı ölçüde düşürdüğü saptanmıştır (Hendijani ve ark., 2018). 
Avrupa Bilim ve Teknoloji Dergisi

Tablo 5. Probiyotik Gldaların Sağllk Etkileri ile İlgili Tüketicilerin Öngörüleri

\begin{tabular}{|c|c|c|c|c|c|c|}
\hline & \multicolumn{2}{|c|}{ Katıllyorum } & \multicolumn{2}{|c|}{ Katılmıyorum } & \multicolumn{2}{|c|}{ Kararsizım } \\
\hline Sağlık Etkileri & $\mathbf{n}$ & $\%$ & $\mathrm{n}$ & $\%$ & $n$ & $\%$ \\
\hline $\begin{array}{l}\text { Bağırsak Sisteminin Düzenlenmesi ve } \\
\text { Kolon Kanserine Karşı Koruyucu }\end{array}$ & 69 & 61,6 & 6 & 5,4 & 34 & 30,4 \\
\hline $\begin{array}{l}\text { Kolesterolün Azalması ve Kalp-damar } \\
\text { Hastalıklarına Karşı Koruyucu }\end{array}$ & 46 & 41,1 & 5 & 4,5 & 59 & 52,7 \\
\hline $\begin{array}{l}\text { Bağışıklık Sisteminin Aktivasyonunda } \\
\text { Etkili }\end{array}$ & 72 & 64,3 & 4 & 3,6 & 34 & 30,4 \\
\hline
\end{tabular}

\section{Sonuç}

Probiyotiklerin sağlık üzerine etkilerini gösteren çalışmaların sayısı her geçen gün artmaktadır. Probiyotiklerin antibiyotik kaynaklı ishaller, atopik hastalıklar ile enflamatuvar barsak hastalıklarındaki tedavi edici etkilerinin yanı sıra tip 2 diyabet, çeşitli kanser türleri, kardiyovasküler hastalıklar gibi kronik hastalıklara karşı koruyucu etkileri olduğu da ortaya çıkarılmıştır. Sağlığı koruyucu ve geliştirici etkileri olan probiyotikler hakkında toplumda var olan bilgi eksikliği bu besinlerin tüketimini de engellemektedir. Toplumun ve bireylerin probiyotik gıdalar hakkındaki bilgi düzeylerinin ve probiyotik gıdaların tüketim sıklıklarının arttırılması toplum sağlığının geliștirilmesi açısından önem taşımaktadır. Bireylerin sıklıkla televizyon, gazete-dergi ve internet yoluyla bilgiye ulaştıkları düşünüldüğünde bu mecralarda konu ile ilgili doğru bilgilerin alanında uzman kişiler tarafından aktarılması büyük önem taşımaktadır.

\section{Kaynakça}

Al-Nabulsi, A.A., Obiedat, B., Ali, R., Osaili, M.T., Bawadi, H., Abushelaibi, A., et al.(2014). Knowledge of probiotics and factors affectıng their consumption by jordanian college students. International Journal of Probiotics and Prebiotics,9(3),77-86.

Altuntaş, Y., Batman, A. (2017). Mikrobiyota ve Metabolik Sendrom. Turk Kardiyol Dern Ars,45(3),286-296.

Ambalam, P., Raman, M., Purama, K.R., Doble, M. (2016). Probiotics, prebiotics and colorectal cancer prevention. Best Pract Res Clin Gastroenterol,30(1),119-131.

Anukam, K.C.(2006) Knowledge of probiotics by Nigerian clinicians. International Journal of Probiotics and Prebiotics,1(1),57-62.

Aydın, M., Açıkgöz, I., Şimşek, B. (2010). Isparta Süleyman Demirel Üniversitesi öğrencilerinin probiyotik ürün tüketimlerinin ve probiyotik kavramının bilinme düzeyinin belirlenmesi. Gıda Teknolojileri Elektronik Dergisi,5(2),1-6.

Bell, V., Ferrão, J., Fernandes, T. (2017). Nutritional guidelines and fermented food frameworks. Foods,6(8),65.

Bjerg, A.T., Kristensen, M., Ritz, C., Holst, J.J., Rasmussen, C., Leser, T.D., et al. (2014). Lactobacillus paracasei subsp paracasei L. casei W8 suppresses energy intake acutely. Appetite,82,111-118.

Coşkun, T. (2006). Probiyotikler, prebiyotikler ve sinbiyotikler. Çocuk Sağlığı ve Hastalıkları Dergisi, 49(2),128-148.

Derin, D.Ö., Keskin, S. (2013). Gıda mühendisliği öğrencilerinin probiyotik ürün tüketim durumlarının belirlenmesi: Ege Üniversitesi örneği. Gıda Dergisi,38(4),215-222.

Ejtahed, H.S., Nia, J.M., Rad, A.H., Jafarabadi, M.A., Mofid, V. (2012). Probiotic yogurt improves antioxidant status in type 2 diabetic patients. Nutrition,28(5),539-543.

Ejtahed, H.S., Nia, J.M., Rad, A.H., Niafar, M., Asghari-Jafarabadi, M., Mofid, V., et al.(2011). Effect of probiotic yogurt containing Lactobacillus acidophilus and Bifidobacterium lactis on lipid profile in individuals with type 2 diabetes mellitus. J Dairy Sci, 94(7),3288-3294.

Gandhi, A., Shah, N.P. (2017). Impact of food unit operations on probiotic microorganisms. In:Sant'Ana AS (Eds). Quantitative Microbiology in Food Processing (p.327-338). West Sussex: John Wiley \& Sons.

Gıda, Tarım ve Hayvancılık Bakanlığı. Türk Gıda Kodeksi Etiketleme Yönetmeliği. Resmi Gazete; 29.12.2011. 41 s. Rapor No:28157

Grajek, W., Olejnik, A., Sip, A. (2005). Probiotics, prebiotics and antioxidants as functional foods. Acta biochimica polonica,52(3),665-671.

Hendijani, F., Akbari, V. (2018). Probiotic supplementation for management of cardiovascular risk factors in adults with type II diabetes: A systematic review and meta-analysis. Clin Nutr.,37(2),532-541.

Jeong, H., Lee, C.Y., Chung, D.K.(2016) Probiotic Lactic Acid Bacteria and Skin Health. Food Science and Nutrition,56(14),2331-7. 
Johnston, B.C., Supina, A.L., Vohra, S. (2006). Probiotics for pediatric antibioticassociated diarrhea: a meta-analysis of randomized placebo-controlled trials. Can Med Assoc J,175,377-383.

Khani, A.H., Jazayeri, S.M., Ebrahimi, E., Younesi-Melerdi, E., Farhadi, A.(2018). The Bifidobacterim bifidum (BIB2) Probiotic Increased Immune System Factors in Men Sprint Athletes. Current Nutrition \& Food Science, 14(4),324-328.

Koçak, H., Kalkan, S. (2014). Üniversite öğrencilerinin probiyotik gıda tüketim alışkanlıklarının belirlenmesi - bahçe meslek yüksekokulu örneği. DBHAD Uluslararası Hakemli Beslenme Araştırmaları Dergisi,1(1),27-31.

Kumar, K.S., Sastry, N., Polaki, H., Mishra1, V. (2015). Colon cancer prevention through probiotics: an overview. Journal of Cancer Science \& Therapy,7(2),81-92.

Laparra, J.M., Sanz, Y. (2010). Interactions of gut microbiota with functional food components and nutraceuticals. Pharmacol Res,61,219-225.

Liu, D.M., Guo, J., Zeng, X.A., Sun, D.W., Brennan, C.S., Zhou, Q.X., et al. (2017). The probiotic role of Lactobacillus plantarum in reducing risks associated with cardiovascular disease. International Journal of Food Science and Technology,52(1),127-136.

McCabe, L., Britton, R.A., Parameswaran, N. (2015). Prebiotic and probiotic regulation of bone health: role of the intestine and its microbiome. Curr Osteoporos Rep, 13(6),363-371.

Milner, J.A. (1999) Functional foods and health promotion. J. Nutrition,129(7),1395-1397.

Nabizadehasl, L. Prebiyotik, probiyotik ve sinbiyotiklerin, kısa ve uzun dönemde tokluk ve besin tüketim üzerine etkisi [Doktora Tezi]. Hacettepe Üniversitesi Sağlık Bilimleri Enstitüsü, Ankara;2018.

Nazarii, K.N., Conte, C., Cammarota, G., Haley, A.P., Styriak, I., Gaspar, L., et al. (2016). Probiotics in prevention and treatment of obesity: a critical view. Nutr Metab (Lond),13,1-14.

Saez, M.J., Sanchez, C.R., Ojeda, J.R., Diaz, J.P., Gil, A. (2016). Effects of probiotics and synbiotics on obesity, insulin resistance syndrome, type 2 diabetes and non-alcoholic fatty liver disease: a review of human clinical trials. Int J Mol Sci, 17(6),1-15.

Stanczak, M., Heuberger, R.(2009). Assessment of the knowledge and beliefs regarding probiotic use. American Journal of Health Education,40(4),207-211.

Thushara, R.M., Gangadaran, S., Solati, Z., Moghadasian, M.H.(2016). Cardiovascular benefits of probiotics: a review of experimental and clinical studies. Food Funct, 7,632-642.

Yabanc1, N., Şimşek, I. (2007). Üniversite öğrencilerinin probiyotik ürün tüketim durumları. TSK Koruyucu Hekimlik Bülteni,6(6),449-454.

Yu, A., Li, L.(2016) The potential role of probiotics in cancer prevention and treatment. Nutr Cancer,68(4),535-544. 